\title{
Growth And Development Of Veined Rapa Whelk Rapana Venosa Veligers
}

JM Harding

Follow this and additional works at: https://scholarworks.wm.edu/vimsarticles

Part of the Marine Biology Commons

\section{Recommended Citation}

Harding, JM, "Growth And Development Of Veined Rapa Whelk Rapana Venosa Veligers" (2006). VIMS Articles. 447.

https://scholarworks.wm.edu/vimsarticles/447

This Article is brought to you for free and open access by W\&M ScholarWorks. It has been accepted for inclusion in VIMS Articles by an authorized administrator of W\&M ScholarWorks. For more information, please contact scholarworks@wm.edu. 


\title{
GROWTH AND DEVELOPMENT OF VEINED RAPA WHELK RAPANA VENOSA VELIGERS
}

\author{
JULIANA M. HARDING \\ Department of Fisheries Science, Virginia Institute of Marine Science, P. O. Box 1346, \\ Gloucester Point, Virginia 23062
}

\begin{abstract}
Planktonic larvae of benthic fauna that can grow quickly in the plankton and reduce their larval period duration lessen their exposure to pelagic predators and reduce the potential for advection away from suitable habitats. Veined rapa whelks (Rapana venosa, Muricidae) lay egg masses that release planktonic veliger larvae from May through August in Chesapeake Bay, USA. Two groups of veliger larvae hatched from egg masses during June and August 2000 were cultured in the laboratory. Egg mass incubation time (time from deposition to hatch) ranged from $18-26 \mathrm{~d}$ at water temperatures between $22^{\circ} \mathrm{C}$ and $27^{\circ} \mathrm{C}$. Four stages of rapa whelk veliger development along a time series from hatch to settlement were described using external morphological features. Rapa whelk veligers were measured at three-day intervals from hatching through the onset of spontaneous settlement. A four-parameter Gompertz growth model was used with length at age data from cultures of rapa whelk veligers to estimate maximum growth rates for June and August hatched groups. Larval rapa whelks settled at shell lengths of 1.18-1.24 mm after planktonic larval periods ranging from 24-42 d. Maximum larval growth rates observed in August $\left(0.03 \mathrm{~mm} \mathrm{~d}^{-1}\right)$ are $50 \%$ lower than maximum larval growth rates observed for June hatched rapa whelk veligers $\left(0.071 \mathrm{~mm} \mathrm{~d}^{-1}\right)$. Daily larval growth rates from hatch to first spontaneous settlement for rapa whelk veligers ranged from $0.002-0.099 \mathrm{~mm} \mathrm{~d}^{-1}$ with maximum growth rates occurring between 12-18 $\mathrm{d}$ post hatch in June. Larval period duration, or the time from hatch to first spontaneous settlement, was 12 days shorter for June hatched larvae than for August hatched larvae. Water temperature was not significantly correlated with larval growth rates $\left(\mathrm{mm} \mathrm{d}^{-1}\right)$ in either June or August. Plasticity in larval period duration may enhance survival and dispersal opportunities for planktonic rapa whelk veligers.
\end{abstract}

KEY WORDS: veined rapa whelk, Rapana venosa, veliger, plankton, larval growth rate, propagule pressure, Muricid, gastropod

\section{INTRODUCTION}

Many benthic invertebrates rely on planktotrophic development of larval forms as part of their life history strategies. Although planktonic larvae are vulnerable to pelagic predators and advection away from suitable habitats (Crisp 1974), planktonic development is a means to avoid benthic predators immediately after emerging from egg capsules and provides a mechanism for genetic exchange and dispersal (Scheltema 1971). Larvae with faster growth rates reduce their exposure to planktonic predators and dispersal vectors and potentially increase the number of larvae that survive to settlement. At the end of planktonic development, larvae settle to the benthos and spontaneously metamorphose losing specialized swimming structures in the process. The transition from pelagic to benthic lifestyle may be delayed in marine gastropods and the length of this delay may be related to the rate of larval development in the plankton (Pechenik 1980, Pechenik \& Lima 1984), the presence of suitable settlement habitat (Crisp 1974, Pechenik 1980), and, in the case of larvae that use particular benthic prey, the presence of suitable prey items at settlement sites (Crisp 1974, Pawlik 1992, Davis \& Stoner 1994).

Veined rapa whelks (Rapana venosa) are a recent addition to Chesapeake Bay's gastropod fauna. Native to Japanese and Korean waters, rapa whelk adults and egg masses were collected from Chesapeake Bay, USA in 1998 (Harding \& Mann 1999). Native channeled whelks (Busycotypus canaliculatus), knobbed whelks (Busycon carica), Atlantic oyster drills (Urosalpinx cinerea) and Thick-lipped oyster drills (Eupleura caudata) all lay egg masses, which release fully developed juvenile snails that walk out of egg cases and begin benthic residence. In contrast, adult rapa whelks lay egg masses that release swimming veliger larvae, which develop in the plankton for 3-4 wk (Harding \& Mann 2001) before eventually settling onto hard substrates, undergoing metamorphosis and taking up residence in the benthos. The period of plank-

E-mail: jharding@ vims.edu tonic larval development may facilitate rapa whelk genetic exchange and dispersal into new habitats while reducing exposure to benthic predators prior to metamorphosis. The presence of a planktonic larval stage has enabled rapa whelk larvae to be moved across natural zoogeographic boundaries in ballast water of commercial ships and, within an estuary, may enhance dispersal and survival to recruitment with the end product being a net increase in propagule pressure, the rate at which breeding individuals are recruited to the population (Williamson 1996), and increased colonization success. The objectives of this study are to qualitatively describe rapa whelk veligers throughout their period of planktonic development and quantitatively describe growth rates of cultured rapa whelk larvae.

\section{MATERIALS AND METHODS}

\section{Egg Mass Sources and Culture}

Adult rapa whelk broodstock were held in flow-through systems at ambient temperature and salinity conditions in the lower York River, Gloucester Point, Virginia with food (hard clams (Mercenaria mercenaria) and oysters (Crassostrea virginica), Harding \& Mann 1999) available in excess.

During 2000, a subset of the egg masses produced by the broodstock populations in June and July were set aside for larval culture and description of larval development. Immediately after removal from the broodstock tanks, each egg mass destined for larval culture was placed in an individual container with $1 \mathrm{~L}$ of 5 - $\mu \mathrm{m}$ filtered seawater. The water in egg mass culture beakers was changed every other day. Egg mass incubation time (time from deposition to hatch or release of swimming veliger larvae) at ambient York River, Virginia conditions was recorded for each egg mass.

\section{Veliger Culture}

Egg masses that hatched on June 21 and 23 and August 1, 2000 provided rapa whelk veligers for descriptions of larval develop- 
ment and growth. After hatching or release of swimming veliger larvae from an egg mass, rapa whelk veligers were filtered from egg mass culture water using $80 \mu \mathrm{m}$ Nytex sieves and cultured in aerated filtered $(5 \mu \mathrm{m})$ seawater $(15-22 \mathrm{ppt})$ at temperatures of $25^{\circ} \mathrm{C}$ to $29^{\circ} \mathrm{C}$ and densities of $<700$ veligers $\mathrm{L}^{-1}$. Veligers were fed a mixed algal diet (Pseudoisochrysis sp., Chaetocerous sp., Tetrasalmis $\mathrm{sp}$.) every other day and were maintained at $10 \mathrm{~h}$ dark/14 $\mathrm{h}$ light conditions.

\section{Observations on Larval Development and Measurements of Larval Growth}

A minimum of nine individual veliger larvae were removed from cultures and narcotized with a $7.5 \%$ magnesium chloride/ seawater solution every three days from hatch (day 0) through the date of first natural spontaneous settlement of veligers within cultures. When veligers were sufficiently narcotized to stop swimming and rest on the bottom of the dish with vela extended and filtering, individual veligers were examined under a dissecting microscope to verify that they were alive and photographed with an image analysis system. After image capture, veligers were placed in $100 \%$ filtered seawater (equivalent to larval culture water), examined to verify that the effects of magnesium chloride had worn off, and returned to their original larval culture. Measurements of veliger shell length (SL, distance from the tip of the spire to the end of the siphonal canal to the nearest $0.001 \mathrm{~mm}$ ) were made from the digital images using an image analysis system.

\section{Data Analyses}

Significance levels for all analyses were established a priori at $P=0.05$. Assumptions of homogeneity of variance were tested with Bartlett tests and assumptions of normality were tested using the Ryan-Joiner test for normality.

Larval culture water temperatures from day of hatch to day of first spontaneous settlement for June and August hatched cultures were compared using a 1-way ANOVA with month of hatch as a factor. Temperature data satisfied assumptions of normality and homogeneity of variance without transformation.

Four parameter Gompertz models were used to describe rapa whelk larval growth in terms of shell length (mm) at age (d) data for presettlement and settlement stage rapa whelk veligers hatched in June and August using the equation:

$$
\mathrm{L}=\mathrm{L}_{0}+\mathrm{a} \mathrm{e}^{-\mathrm{e}^{-\left(\frac{t-t_{0}}{\mathrm{~b}}\right)}}
$$

where $\mathrm{L}_{0}$ is the veliger shell length (mm) at hatch or $t=0, t$ is time posthatch or age in days, $t_{0}$ is the time corresponding to the midpoint of the rise, $a$ is the maximum attainable larval size, and $b$ is a rate constant . Maximum growth rate during the larval period was calculated using the equation:

$$
\text { Maximum growth rate }\left(\mathrm{mm} \mathrm{d}^{-1}\right)=0.368\left(\frac{\mathrm{a}}{\mathrm{b}}\right)
$$

The Gompertz model has previously been used to describe molluscan growth on a length at age basis (Devillers et al. 1998, Chicharo \& Chicharo 2000, Rodriguez et al. 2001). The fourparameter model was used because it incorporates larval size at hatching from the egg cases.

Larval growth rates at intervals during larval development were estimated for three-day intervals between measurements using the formula:

$$
\text { growth rate }\left(\mathrm{mm} \mathrm{d}^{-1}\right)=\frac{\begin{array}{l}
\text { Average shell length }(\mathrm{mm})_{\mathrm{t}+3 \mathrm{~d}} \\
- \text { Average shell length }(\mathrm{mm})_{\mathrm{t}}
\end{array}}{3 \mathrm{~d}}
$$

where $t$ is the time post hatch or age in days. Average shell lengths were used because veliger growth rates were measured sequentially as groups randomly chosen from cultures instead of following individual veliger larvae for the duration of planktonic development. Linear regression analyses were used to evaluate the relationship between daily larval growth rate $(\mathrm{mm})$ and water temperature $\left({ }^{\circ} \mathrm{C}\right)$.

\section{RESULTS}

In 2000, egg mass deposition in rapa whelk broodstock tanks began on May 15 and continued through August 15. Egg masses hatched June 21 through 23 were deposited between May 15 and June 6 with an average incubation time of $26.3 \pm 2.3 \mathrm{~d}$ (standard error) at average water temperatures of $22.6^{\circ} \mathrm{C} \pm 0.31^{\circ} \mathrm{C}$. Egg masses hatched August 1 were deposited on July 14 with an incubation time of $18 \mathrm{~d}$ at average water temperatures of $27.2^{\circ} \mathrm{C} \pm$ $0.18^{\circ} \mathrm{C}$. Chung et al. (1993) describe an incubation period of $17 \mathrm{~d}$ from deposition to hatch for rapa whelk egg cases from Korean waters in the laboratory at water temperatures of $18.3^{\circ} \mathrm{C}$ to $20.4^{\circ} \mathrm{C}$.

For descriptive purposes, rapa whelk veligers along the continuum of development were assigned to one of four groups on the basis of visible morphological features. Davis et al. (1993) used a similar development scheme for three species of Strombas larvae. All references to age in days use the hatch date $(0 \mathrm{~d})$ as a starting point and are thus days-post hatch. Pictures of larval rapa whelk veligers are presented for all four developmental stages in Figure 1 .

Stage I rapa whelk veligers ( $0-5 \mathrm{~d}$ ) had a bilobed velum, a translucent foot and visible eye stalks (Fig. 1A). Their brown shells were smoothly rounded at the spire (Fig. 1A) with the development of the first whorl beginning 5-6 d post hatch. The beak and columella were visible at hatch and grew quickly, often presenting an almost translucent shell layer that gradually darkened with age (Fig. 1A, B). The beating heart was clearly visible through the shell at hatch. Two rows of cilia were visible along the outer edge of the velar lobes after $2 \mathrm{~d}$ (Fig. 1B). Veliger shell length at hatch estimates were between 0.406 (June) and 0.412 (August) mm (Table 1). Actual shell measurements were not made on veligers at hatch $(0 \mathrm{~d})$ because the rounded shell morphology made it impossible to position specimens (narcotized or not) on a single level plane under the microscope for image capture.

Stage II veligers (6-9 d) had an elongated beak, a four lobed velum with approximately proportionate lobes, and a relatively small opaque foot (Fig. 1C,D). By 6 d, one complete body whorl and shell shoulder were present (Fig. 1C) and the spiral line on the body whorl left by the presuture of the beak was obvious. Antennae were visible posterior to the eyestalks at day 9 (Fig. 1D).

Stage III veligers (10-23 d) continued to have an elongated beak with a suture in the middle and a proportionate four lobed velum but the foot was white and muscular with visible muscular contractions and greatly increased range of mobility (Fig. 1E,F). During Stage III, the foot began to have distinguishable anterior and posterior regions and became spade shaped. The operculum was clearly visible by $18 \mathrm{~d}$. At $12-15 \mathrm{~d}$, the larval shell was dark brown with two prominent shell shoulders, a well-developed col- 

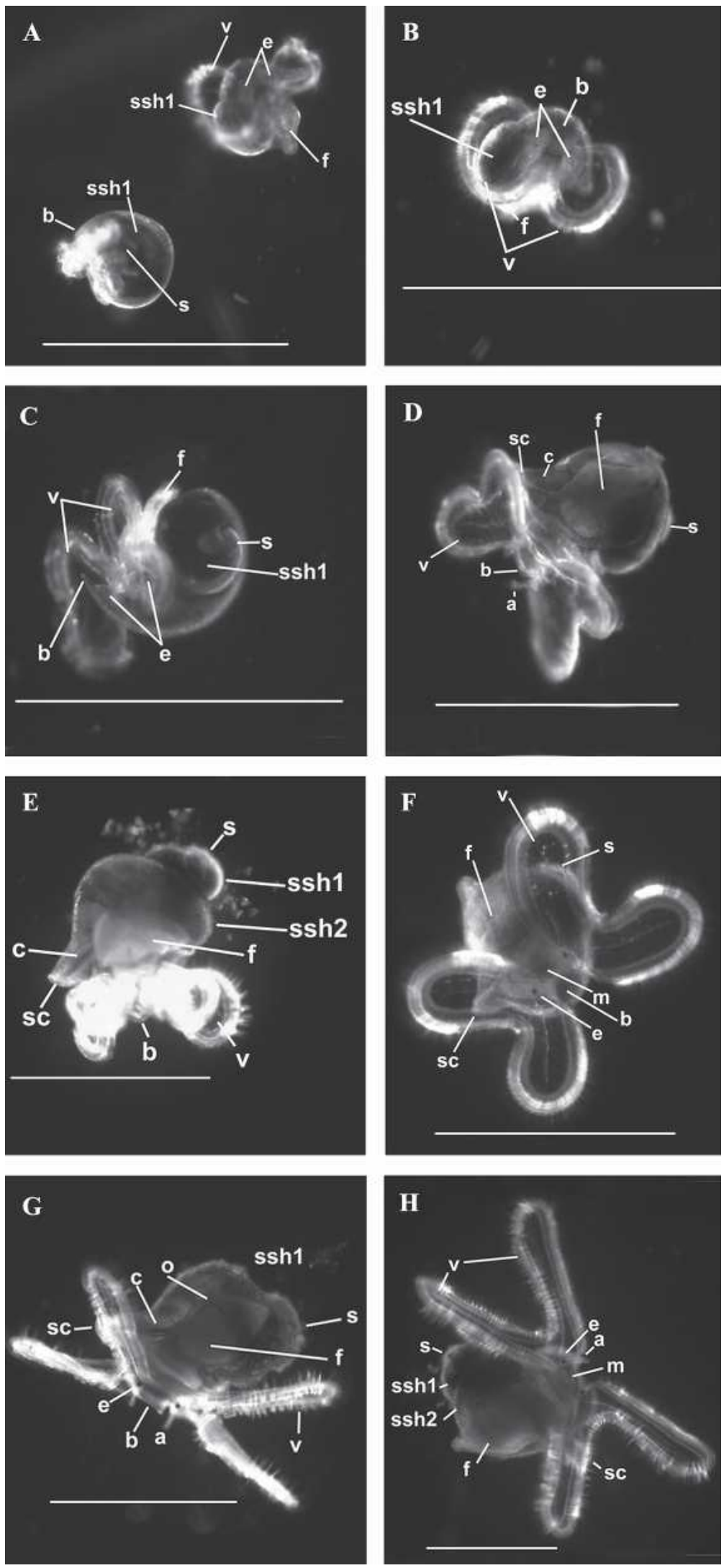

Figure 1. Pictures of rapa whelk (Rapana venosa) veligers in Stage I (A: 2-d-old veliger, B: 5-d-old veliger), Stage II (C: 6-d-old veliger, D: 9-d-old veliger), Stage III (E: 12-d-old veliger, F: 15-d-old veliger) and Stage IV (G: 38-d-old veliger, H: 23-d-old veliger). The scale bar in each picture represents $1 \mathrm{~mm}$. Morphological features are noted, including the antenna (a), shell beak (b), columella (c.), eye stalks (e), foot (f), mouth (m) operculum (o), siphonal canal (sc), first shell shoulder (ssh1), second shell shoulder (ssh 2), spire (s) and velum (v). 
TABLE 1.

Model coefficients for four parameter Gompertz regressions used to describe rapa whelk larval growth with standard error estimates for model coefficients in parentheses.

\begin{tabular}{lccccc}
\hline \hline Hatch month & $\mathbf{a}$ & $\mathbf{b}$ & $\mathbf{t}_{\mathbf{0}}$ & $\mathbf{L}_{\mathbf{0}}$ & $\mathbf{M o d e l ~ R}^{\mathbf{2}}$ \\
\hline June & $0.869(0.044)$ & $4.478(0.538)$ & $13.963(0.376)$ & $0.406(0.023)$ & 0.88 \\
August & $1.139(0.153)$ & $12.258(1.967)$ & $29.826(1.718)$ & $0.412(0.014)$ & 0.86 \\
\hline
\end{tabular}

umella and siphonal canal, and visible rounded bumps/dimples on the exterior shell surface (Fig. 1E). By 18-21 d, a third shell shoulder was visible.

Stage IV veligers ( $24 \mathrm{~d}$-settlement) had a prominent siphon that was typically extended from the siphonal canal and a four lobed velum where the anterior lobes were slightly larger than the posterior lobes (Fig. 1G,H). Veligers were competent to settle from 24 $\mathrm{d}$ forward, with size at settlement ranging from $1.18 \pm \mathrm{SE} 0.03 \mathrm{~mm}$ (August) to $1.24 \pm 0.03 \mathrm{~mm}$ (June). By $27 \mathrm{~d}$, three complete shell whorls were present with three distinct shell shoulders. All four lobes of the velum began elongating at $30 \mathrm{~d}$ becoming almost finger-like by $33 \mathrm{~d}$. The foot continued to grow and became spade shaped (Fig. 1G,H). As the veligers aged, the beak gradually become less elongate and by $30 \mathrm{~d}$ was recognizable as only a simple point in swimming veligers. By $30 \mathrm{~d}$, veligers spent at least half of the time with their velum retracted and the foot extended and probing available hard surfaces. At settlement, the shell was dark brown/black and the operculum had grown to the same size as the opercular opening and had dark brown/black edges with a light brown center.

Veligers hatched in June began settling at $24 \mathrm{~d}$ with all June cultures achieving settlement by $30 \mathrm{~d}$. Veligers from all three August hatched cultures settled at $42 \mathrm{~d}$. Larval culture water temperatures for June and August hatched animals were not significantly different (ANOVA, $\mathrm{F}=0.65, P=0.42$ ).

Larval shell lengths increased rapidly between 9 and $21 \mathrm{~d}$ (Fig. 2A) for June hatched veligers. This time window corresponds developmentally and morphologically to Stage III when veligers had a 4-lobed velum, developing foot, and the shell attained its second shoulder or whorl (see earlier). Shell lengths for August hatched veligers increased more slowly throughout larval life (Fig. $3 \mathrm{~A}$ ) and August hatched veligers took $12 \mathrm{~d}$ longer to settle than June hatched veligers.

Maximum growth rates for June hatched veligers $(0.071 \mathrm{~mm}$ $\mathrm{d}^{-1}$ ) were twice as high as maximum growth rates observed for August hatched veligers $\left(0.033 \mathrm{~mm} \mathrm{~d}^{-1}\right)$. Estimated daily larval growth rates from hatch to first spontaneous settlement for rapa whelk veligers ranged from $0.002-0.099 \mathrm{~mm}^{-1 a y}{ }^{-1}$ and were generally higher during Stages I through III for June hatched veligers than for August hatched veligers (Fig. 2B and 3B). August hatched veligers were in Stage IV for longer than June hatched veligers and experienced higher relative growth rates than June hatched veligers at 24 and $27 \mathrm{~d}$ in Stage IV (Fig. 2B and 3B). It should be noted, however, that all June hatched veligers had settled by $30 \mathrm{~d}$ post hatch, whereas August hatched veligers did not settle until 42 d post hatch.

Larval culture water temperatures from June 21 and 23 (hatch dates) through July 15 (date of first settlement) ranged from $25.1^{\circ} \mathrm{C}$ to $27.9^{\circ} \mathrm{C}$ with a mean of $26.6^{\circ} \mathrm{C}$ (standard error $\pm 0.17^{\circ} \mathrm{C}$ ) with residual water temperatures typically within 1 degree of the mean (Fig. 2C). Larval culture water temperatures from August 1 (hatch date) through September 11 (42 d, date of settlement) ranged from $25.3^{\circ} \mathrm{C}$ to $28.3^{\circ} \mathrm{C}$ with a mean of $26.6^{\circ} \mathrm{C}$ (standard error $\pm 0.18^{\circ} \mathrm{C}$ ) with residual water temperatures up to $1.5^{\circ} \mathrm{C}$ of the mean (Fig. 3C). Water temperature was not significantly correlated with larval growth rates $\left(\mathrm{mm} \mathrm{d}^{-1}\right)$ in either June $(\mathrm{df}=1, \mathrm{~F}=$ $0.43, P=0.52$ ) or August ( $\mathrm{df}=1, \mathrm{~F}=0.10, P=0.75$ ).

\section{DISCUSSION}

Larval rapa whelks settled at shell lengths of 1.18-1.24 mm after planktonic larval periods ranging from 24-42 d. Maximum larval growth rates observed in August $\left(0.03 \mathrm{~mm} \mathrm{~d}^{-1}\right)$ are $50 \%$ lower than maximum larval growth rates observed for June hatched rapa whelk veligers $\left(0.071 \mathrm{~mm} \mathrm{~d}^{-1}\right)$. Dobberteen and Pechenik (1987) observed growth rates of $0.027 \mathrm{~mm} \mathrm{~d}^{-1}$ for 0-28 $\mathrm{d}$ old Thais haemastoma canaliculata maintained at $24^{\circ} \mathrm{C}$ in labo-
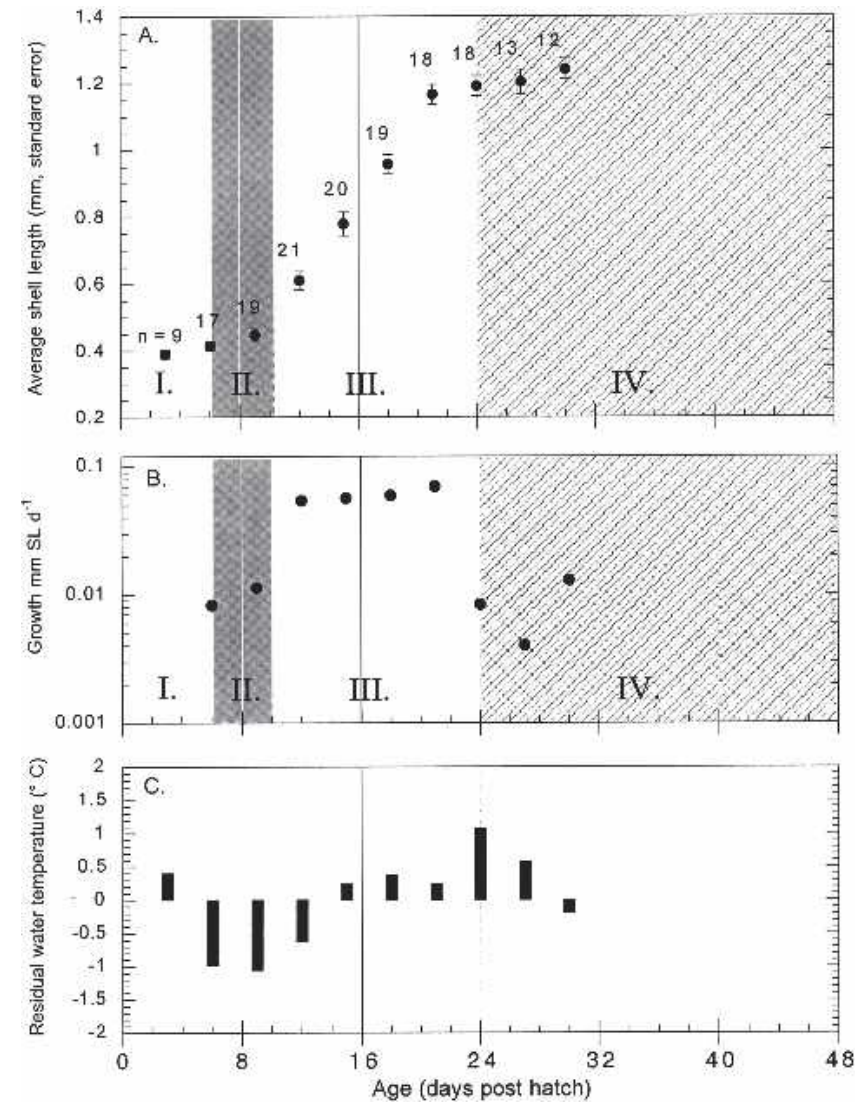

Figure 2. June hatched rapa whelk veliger $(A)$ shell length $(\mathrm{mm})$ at age (d) relationship, (B) growth rate ( $\mathrm{mm}$ shell length $\mathrm{d}^{-1}$ through planktonic development and $(\mathrm{C})$ larval culture water temperature residuals $\left({ }^{\circ} \mathrm{C}\right)$ from the average larval culture water temperatures from hatch through $30 \mathrm{~d}$. 

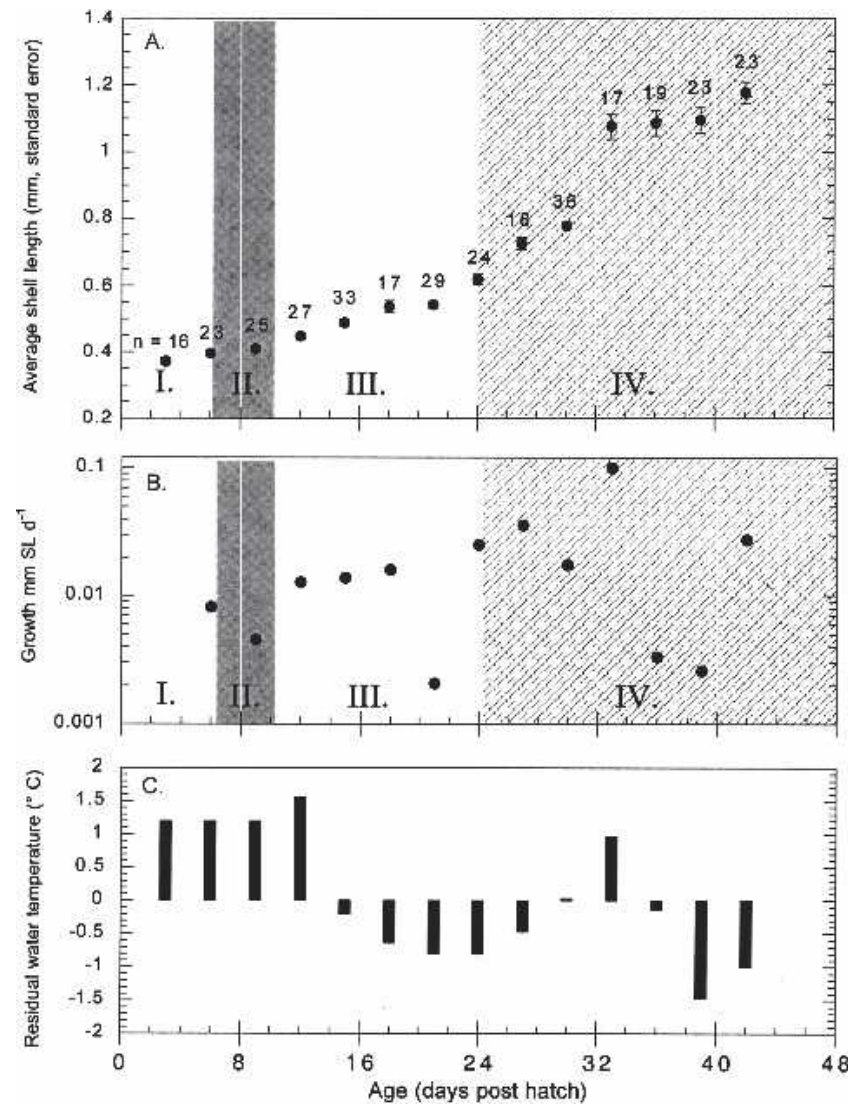

Figure 3. August hatched rapa whelk veliger (A) shell length $(\mathrm{mm})$ at age (d) relationship, (B) growth rate $\left(\mathrm{mm}\right.$ shell length $\mathrm{d}^{-1}$ through planktonic development, and $\mathrm{C}$ ) larval culture water temperature residuals $\left({ }^{\circ} \mathrm{C}\right)$ from the average larval culture water temperatures from hatch through $42 \mathrm{~d}$.

ratory cultures. Daily larval growth rates from hatch to first spontaneous settlement for rapa whelk veligers ranged from 0.002 $0.099 \mathrm{~mm} \mathrm{~d}^{-1}$ with maximum growth rates occurring between $12-18$ d post hatch in June. The differences in daily growth rates observed through development (this study) may explain the reductions in rapa whelk veliger survivorship and salinity tolerance observed by Mann and Harding (2003) at $12-18$ d post hatch. The Stage III period in larval development is probably physiologically stressful because of the observed rapid shell growth. June hatched veligers approximately doubled their shell lengths during Stage III (12 d, $0.447 \mathrm{~mm} ; 18 \mathrm{~d}, 0.958 \mathrm{~mm}$ ). This trend was less noticeable for August hatched veligers whose overall growth rates were slower and settlement sizes were smaller.

Observed differences in growth rates and size at settlement between June and August hatched veligers may be related to culture conditions, parental physiological condition as expressed in the egg mass, or these differences may simply reflect a range of developmental plasticity within the species. Although average culture water temperatures $\left(26.6^{\circ} \mathrm{C}\right)$ were the same for June and $\mathrm{Au}$ gust larval periods, culture water temperatures were $1-2^{\circ} \mathrm{C}$ above average in early August for the first 6-9 d of larval development. Thermal tolerances of rapa whelk veligers are unknown, but slower growth rates early in larval life may have been related to thermal stress caused by warmer water temperatures. Rapa whelks lay multiple egg masses within a single breeding season (Chung et al. 1993, Harding \& Mann 1999). In Chesapeake Bay, rapa whelks begin laying eggs in May and egg laying continues through August (Mann \& Harding 2003). The egg masses used herein were laid from mid-May to early June (June hatch) at the beginning of the adult egg mass laying period and mid-July (August hatch) towards the end of egg mass laying activity. Seasonal decreases in reproductive investment (as indicated by egg size or number per egg mass) have been documented for a marine polychaete (Qian \& Chia 1992) and other marine molluscs (Ito 1997) with trends in decreasing number of eggs per clutch (egg mass) and egg size from the beginning to the end of the breeding season related to parental physiology and/or nutritional state. The egg masses used in this study were from multiple wild caught females. Information on adult condition before or at egg laying was not available. The position of each egg mass cultured for this study in the sequence of egg masses produced by each female in this breeding season is also unknown.

One of the most vulnerable portions of the rapa whelk life cycle is the period of planktonic larval development. Larvae that grow quickly in the plankton and reach competence quickly, reduce their exposure to planktonic sources of mortality. Relatively large size at competence increases postsettlement survivorship. Average rapa whelk shell length at settlement $(1.18-1.24 \mathrm{~mm})$ is similar to reported size at settlement for other gastropod larvae including Thais kieneri (1.04 mm, Middlefart 1996), Stramonita (Thais) haemastoma $(0.800 \mathrm{~mm}$, Butler 1954), and Strombas gigas $(1.170 \mathrm{~mm}$, Davis et al. 1993). However, R. venosa size at settlement is approximately twice that of Rapana rapiformis $(0.520-0.540 \mathrm{~mm}$, Ramesh 1999) although both metamorphose and settle as early as 24 d post hatch ( $R$. rapiformis, Ramesh 1999; $R$. venosa, this study). Moran (1999) predicts a positive relationship between growth, survivorship and size at settlement for intertidal gastropods. Large size at settlement brings with it increased resistance to starvation (Moran 1999) and reduced vulnerability to benthic predators (Spight 1976, Gosselin 1997).

The observed differences in larval growth rates and larval period duration may affect recruitment success of individual animals and invasion potential of the species as a whole. Animals that settle early in the year will be exposed to a longer growing season during their first year and, as a consequence, reach sexual maturity more quickly than animals that settle later in the year. From the standpoint of biological invasions, animals that grow rapidly to reproductive maturity increase the propagule pressure (Williamson 1996) within a habitat. The observed plasticity in rapa whelk growth rate and larval period duration resulting in successful settlement directly relates to the potential viability of larvae entrained and transported in ballast water as well as the survival of these larvae after introduction into new habitats. This plasticity may explain, at least to some degree, the continued success of rapa whelk invasions into new habitats. Recent invasions by rapa whelks include the Rio de la Plata, Uruguay and Argentina (Pastorino et al. 2000) and the Scheveningen, Netherlands (Vink et al. 2005). Historically, large long-lived gastropods like rapa whelks were not among the candidate fauna for anthropogenic transport to other habitats (Carlton 1999) and geographic range expansion by these benthic infauna relied on slow progression of individuals crawling into new areas or dispersal of planktonic larvae by water currents within the established range of ecological tolerances. Modern reliance on ballast water as part of commercial shipping offers a rapid vector for dispersal of the larval forms of these large predatory gastropods that supercedes natural zoogeographic boundaries and results in deposition of larval forms that have 
evolved under one set of ecological and environmental constraints into new habitats lacking these traditional controls.

\section{ACKNOWLEDGMENTS}

The author thanks all of the local citizens, watermen, and seafood processors that have donated adult Rapana to our research program. P. Crewe, K. Farnsworth, S. Goodbred, C. Goodbred, R. Mann, M. Mann, K. Mann, M. Southworth, and C. Tomlinson assisted with local whelk collection. D. Dolittle, R. Howlett, D. Jones, D. Kerstetter, P. Kingsley-Smith, R. Mann, D. Savini, M. Southworth, C. Ware, and E. Westcott provided assistance with larval culture. D. Findley, D. Sennett and A. Arseniu of the
Virginia Institute of Marine Science Aquaculture Breeding and Technology Center supplied algae for larval cultures. D. Dolittle, R. Howlett, D. Kerstetter, and C. Ware helped with image acquisition, laboratory measurements, and data entry. D. Evans provided statistical advice. R. Mann and M. Southworth provided valuable comments on earlier drafts of this manuscript. Support for this project was provided by the NOAA/National Sea Grant Aquatic Nuisance Species Research and Outreach Program (NA96RG0025/5-29456), Virginia Sea Grant (R/MG-98-3), and the Virginia Institute of Marine Science Department of Fisheries Science. This is Contribution number 2753 from the Virginia Institute of Marine Science.

\section{LITERATURE CITED}

Butler, P. 1954. The southern oyster drill. Proc. Natl. Shellfish. Assoc. 44:67-75.

Carlton, J. 1999. Molluscan invasions in marine and estuarine communities. Malacologia. 41:439-454.

Chicharo, L. M. \& A. M. Chicharo. 2000. Estimation of life history parameters of Mytilus galloprovincialis (Lamark) larvae in a coastal lagoon (Rio Formosa, south Portugal). J. Exp. Mar. Biol. Ecol. 243:8194.

Chung, E. Y., S. Y. Kim \& Y. G. Kim. 1993. Reproductive ecology of the purple shell, Rapana venosa (Gastropod: Muricidae), with special reference to the reproductive cycle, deposition of egg capsules and hatching of larvae. Korean Journal of Malacology. 9(2):1-15.

Crisp, D. J. 1974. Factors influencing the settlement of marine invertebrate larvae. In: P. T. Grant \& A. M. Mackie, editors. Chemoreception in marine organisms. New York: Academic Press. pp. 177-265.

Davis, M., C. Bolton \& A. Stoner. 1993. A comparison of larval development, growth, and shell morphology in three Caribbean Strombas species. Veliger 36(3):236-244.

Davis, M. \& A. W. Stoner. 1994. Trophic cues induce metamorphosis of queen conch larvae (Strombas gigas Linneaus). J. Exp. Mar. Biol. Ecol. 180:83-102.

Devillers, N., A. G. Eversole \& J. J. Isely. 1998. A comparison of four growth models for evaluating growth of the northern quahog Mercenaria mercenaria (L.). J. Shellfish Res. 17(1):191-194.

Dobberteen, R. \& J. Pechenik. 1987. Comparison of larval bioenergetics of two marine gastropods with widely differing lengths of planktonic life, Thais haemastoma canaliculata (Gray) and Crepidula fornicata (L.). J. Exp. Mar. Biol. Ecol. 109:173-191.

Gosselin, L. 1997. An ecological transition during juvenile life in a marine snail. Mar. Ecol. Prog. Ser. 157:185-194.

Harding, J. M. \& R. Mann. 1999. Observations on the biology of the veined rapa whelk, Rapana venosa (Valenciennes, 1846) in the Chesapeake Bay. J. Shellfish Res. 18(1):9-18.

Harding, J. M. \& R. Mann. 2001. Growth rates of larval and juvenile veined rapa whelks Rapana venosa from Chesapeake Bay USA from hatch through Age 1. (J. Pederson, editor). Marine Bioinvasions: Proceedings of the Second International Conference, April 9-11, 2001. New Orleans, LA.

Ito, K. 1997. Egg size and number variations related to maternal size and age, and the relationship between egg size and larval characteristics in an annual marine gastropod, Haloa japonica (Opisthobranchia; Cephalaspidea). Mar. Ecol. Prog. Ser. 152:187-195.

Mann, R. \& J. M. Harding. 2003. Salinity tolerances of larval Rapana venosa: implications for dispersal and establishment of an invading predatory gastropod on the North American Atlantic coast. Biol. Bull. 204:96-103.

Middlefart, P. 1996. Egg capsules and early development of ten muricid gastropods from Thai waters. Phuket Marine Biological Center special publication, No. 16 pp.103-130.

Moran, A. 1999. Size and performance of juvenile marine invertebrates: potential contrasts between intertidal and subtidal benthic habitats. Am. Zool. 39:304-312.

Pawlik, J. R. 1992. Chemical ecology of the settlement of benthic marine invertebrates. Oceanogr. Mar. Biol. Annu. Rev. 30:273-335.

Pastorino, G., P. Penchaszadeh, L. Schejter \& C. Bremec. 2000. Rapana venosa (Valenciennes, 1846) (Mollusca: Muricidae): A new gastropod in south Atlantic waters. J. Shellfish Res. 19(2):897-899.

Pechenik, J. A. 1980. Growth and energy balance during the larval lives of three prosobranch gastropods. J. Exp. Mar. Biol. Ecol. 44:1-28.

Pechenik, J. A. \& G. M. Lima. 1984. Relationship between growth, differentiation, and length of larval life for individually reared larvae of the marine gastropod Crepidula fornicata. Biol. Bull. 166:537-549.

Qian, P. \& F. Chia. 1992. Effect of aging on reproduction in a marine polychaete Capitella sp. J. Exp. Mar. Biol. Ecol. 156:23-38.

Ramesh, R. 1999. Spawning and larval development of Rapana rapiformis (Born) (Mollusca: Gastropoda). Phuket Marine Biological Center special publication No. 19(1). pp. 113-117.

Rodriguez, L., G. Daneria, C. Torres, M. Leon \& L. Bravo. 2001. Modeling the growth of the Chilean loco, Concholepas choncolepas (Bruguiere, 1789) using a modified Gompertz-type function. J. Shellfish Res. 20: 309-315.

Scheltema, R. 1971. Larval dispersal as a means of genetic exchange between geographically separated populations of shallow water benthic marine gastropods. Biol. Bull. 140:284-322.

Spight, T. 1976. Ecology of hatching size for marine snails. Oecologia 24:283-294.

Williamson, M. 1996. Biological invasions. New York, USA: Chapman and Hall. 244 pp.

Vink, R., D. Nieweg \& H. Post. 2005. Rapana venosa (Valenciennes, 1846): a new invasive species for the Netherlands (and England?). Spirula 345:152-155 (In Dutch with English abstract). 